\title{
Analisis kebutuhan pengembangan bahan ajar ipa berbasis pbl terintegrasi stem untuk meningkatkan kemampuan berpikir kritis pada materi gerak lurus
}

\author{
Alifia Asterina Putri, Parno*, Yessi Affriyenni \\ Universitas Negeri Malang, Jl. Semarang No. 5 Malang, Jawa Timur, Indonesia \\ *Penulis korespondensi, Surel: parno.fmipa@um.ac.id
}

Paper received: 01-05-2021; revised: 15-05-2021; accepted: 31-05-2021

\begin{abstract}
Abstrak
Bahan ajar ialah salah satu sarana belajar yang bisa digunakan siswa untuk belajar secara mandiri. Tetapi model pembelajaran yang menggunakan permasalahan nyata, menyisipkan aspek STEM, dan menggunakan strategi belajar mandiri belum banyak dikembangkan. Dilihat dari berbagai penelitian masih banyak siswa dengan kemampuan berpikir kritisnya masih rendah dan kesulitan untuk mengaitkan materi pembelajaran dengan permasalahan nyata. Oleh karena itu, penelitian yang dilakukan ini memiliki tujuan untuk mengembangkan serta menguji kelayakan dari bahan ajar dengan PBL-STEM pada materi gerak lurus sehingga layak digunakan sebagai peningkatan kemampuan berpikir kritis pada siswa. Penelitian yang dilakukan menerapkan model pengembangan 4-D dengan tujuan menjelaskan kenaikan kemampuan berpikir kritis melalui bahan ajar IPA berbasis PBL-STEM. Hasil validasi ahli materi menyimpulkan bahwa bahan ajar memiliki persentase kelayakan rata-rata 96 persen, dan validasi ahli media menunjukkan persentase rerata kelayakan 90 persen. Hasil uji keterbacaan oleh guru menyimpulkan jika bahan ajar memiliki persentase keterbacaan rata-rata sebesar 100 persen dan hasil keterbacaan oleh 15 siswa memiliki persentase keterbacaan rata-rata sebesar 100 persen. Sehingga bisa ditarik kesimpulan bahwa bahan ajar IPA dengan PBL-STEM diperoleh hasil sangat layak sehingga berpeluang untuk meningkatkan kemampuan berpikir kritis.
\end{abstract}

Kata kunci: bahan ajar; PBL-STEM; berpikir kritis; gerak lurus

\section{Pendahuluan}

Fisika adalah materi esensial sebagai asas kemajuan teknologi dan ilmu pengetahuan. Upaya peserta didik dalam menggali materi fisika seringkali mendapati kesulitan. Materi fisika sering diibaratkan sebagai pengetahuan yang susah untuk dapat dipahami. Keadaan tersebut menjadikan nilai yang didapat oleh peserta didik menjadi kurang baik (Agus, 2013). Gerak lurus merupakan materi pembelajaran yang dipelajari di kelas VIII SMP. Materi gerak lurus merupakan materi yang penerapannya berkaitan dengan kejadian sehari-hari yang selanjutnya peserta didik diharuskan untuk menguasai teori, menemukan masalah seharihari dan dapat memecahkan permasalahan dengan mengaitkan teori dan konsep yang relevan, tetapi peserta didik kesusahan dalam mengartikan dan menerapkan konsep pada pembelajaran (Catur, 2017). Berdasarkan penelitian oleh Setyorini (2011) melakukan kajian fisika pada pokok bahasan GLB, masih mengalami kesulitan dalam memperlihatkan kejadian nyata pada benda yang bergerak secara konsisten dalam fenomena sehari-hari. Oleh sebab itu, guna mewujudkan peningkatan dengan kategori tinggi, peserta didik harus mempunyai kemampuan berpikir kritis yang tinggi dan diperlukan metode yang tepat.

Menurut Ennis (2011) kemampuan berpikir kritis yakni kebolehan dalam berpikir secara spekulatif dan berpedoman yang ditekankan pada sesuatu yang telah diyakini atau dijalani. Potensi berpikir kritis terdiri dari uraian dasar, pengumpulan ketetapan, meringkas, menyampaikan klarifikasi dan penggabungan, serta keterampilan tambahan. Dari hasil akhir 
penelitian yang dijalankan Lilis (2018) menunjukkan jika keahlian berpikir kritis pada tingkat SMP masih kurang. Peristiwa ini ditunjukkan oleh sedikitnya pencapaian rerata dengan kelompok jawaban Benar (B). Hasil pengamatan penelitian pada saat Kajian dan Praktik Lapangan (KPL) di SMPN 24 Malang terlihat bahwa pembelajaran IPA yang dituntun guru pada kelas VIII masih terlampau banyak yang mengutamakan keterampilan dasar. Hal tersebut tampak dari pertanyaan yang dibagikan ketika ulangan harian yaitu serupa dengan contohnya, kecuali hanya angka yang di ganti. Oleh karena itu, maka diperlukan penelitian lagi yang mengasah kemampuan berpikir kritis siswa dengan bantuan metode dan model pembelajaran secara tepat.

Menurut Cahyaning, dkk (2018) pembelajaran berbasis PBL-STEM mempunyai pengaruh yang sangat signifikan terhadap keahlian berpikir kritis dan juga hasil belajar dengan kategori sedang. Selanjutnya, pada penelitian yang dilaksanakan oleh Laforce, dkk (2017) menunjukkan model PBL menjadi salah satu strategi guna menumbuhkan kapasitas kepada peserta didik dalam bidang STEM. Penelitian terdahulu lainnya yang dilakukan oleh Maqbullah (2018) menunjukkan bahwa PBL dapat memaksimalkan kemampuan keterampilan berpikir kritis pada peserta didik. Bersamaan dengan penyelidikan yang dijalankan Santriani (2017) memperlihatkan bahwa PBL untuk menumbuhkan efektivitas berpikir kritis pada pembelajaran STEM bisa menyampaikan (1) paparan bersahaja, (2) menciptakan kapasitas dasar, (3) mengelola prosedur dan taktik, (4) memberikan perincian lanjutan, serta (5) menarik kesimpulan.

Model PBL terintegrasi STEM yaitu pembelajaran yang diintegrasikan dengan STEM yang bertujuan untuk menumbuhkan kreativitas pada peserta didik dari proses pemecahan masalah pada kehidupan sehari-hari (Winarni, dkk, 2016). Pengintegrasian STEM pada model pembelajaran dengan berbasis masalah dapat mengarahkan peserta didik dalam menyelesaikan permasalahan yang disajikan secara kelompok, dan juga dapat memotivasi peserta didik dalam bekerja sama dan bertanggung jawab dari pekerjaannya dan dapat melakukan diskusi dengan kelompok masing-masing (Farwati, dkk, 2017). Bahan ajar dengan pendekatan PBL-STEM mengemas materi gerak lurus dengan abstrak. Tetapi dengan adanya pendekatan PBL-STEM, peserta didik yang awalnya kesulitan memahami konsep menjadi lebih mudah memahami konsep (Rahmawati, 2016).

Model PBL-STEM dapat dikombinasikan dalam bentuk bahan ajar agar secara berkelompok peserta didik dapat memecahkan suatu permasalahan dengan kritis. Selain itu, model ini juga diharapkan mempermudah peserta didik dalam memahami topik pembelajaran yang diaplikasikan dengan kegiatan pemecahan menggunakan keterampilan berpikir kritis.

\section{Metode}

Penelitian ini yaitu penelitian pengembangan R\&D yang bertujuan untuk mendeskripsikan peningkatan kemampuan berpikir kritis pada peserta didik SMPN 24 Malang melalui bahan ajar berbasis PBL-STEM. Model pengembangan bahan ajar dalam penelitian ini mengaplikasikan metode pengembangan 4-D yang telah dikembangkan oleh Thiagarajan (1974). Pengembangan bahan ajar dengan model 4-D terdiri dari empat tahapan, meliputi: define, design, develop, dan disseminate. 


\section{Hasil dan Pembahasan}

Pada tahapan awal perancangan yaitu pembentukan rancangan pokok bahan ajar dengan struktur bahan ajar yang berisi sampul, daftar isi, kata pengantar, identitas bahan ajar, petunjuk penggunaan, peta konsep, komponen kegiatan, subbab 1, 2, 3, latihan soal, jurnal harian siswa, serta daftar pustaka.

Tahapan pengembangan yaitu diperoleh dari hasil validasi bahan ajar yang telah melalui tahap penilaian dari ahli media, ahli materi, guru, dan siswa. Hasil validasi bahan ajar berlevel sangat baik, kemudian bahan ajar ini telah mencapai kategori dengan sangat layak yang dipergunakan di kegiatan belajar.

Uji kelayakan produk mencakup uji kelayakan buku siswa serta buku guru oleh satu dosen Program Studi Pendidikan IPA Universitas Negeri Malang serta satu guru IPA SMPN 24 Malang yang sedang mengajar kelas VIII serta kompeten mengenai kurikulum 2013 terbaru. Ringkasan hasil rata-rata evaluasi bahan ajar di dalam Tabel 1 berikut.

Tabel 1 Hasil Rata-rata Penilaian Bahan Ajar

\begin{tabular}{lllll}
\hline No. & Aspek yang dinilai & $\begin{array}{l}\text { Rata- } \\
\text { rata }\end{array}$ & $\begin{array}{l}\text { Presentase } \\
\text { Kelayakan }\end{array}$ & Kriteria \\
\hline 1. & Kelayakan materi & 1 & $100 \%$ & Sangat Layak \\
\hline 2. & $\begin{array}{l}\text { Kesesuaian Tahapan PBL- } \\
\text { STEM dengan Indikator } \\
\text { Berfikir Kritis }\end{array}$ & 1 & $100 \%$ & Sangat Layak \\
& $\begin{array}{l}\text { Kesesuaian dengan aspek } \\
\text { STEM }\end{array}$ & 1 & $100 \%$ & Sangat Layak \\
\hline 3. & Kebenaran konsep & 1 & $100 \%$ & Sangat Layak \\
\hline 4. & $\begin{array}{l}\text { Kesesuaian instrumen } \\
\text { penilaian dengan buku }\end{array}$ & 1 & $81 \%$ & Sangat Layak \\
\hline 5. & Kelayakan isi & 1 & $89 \%$ & Sangat Layak \\
\hline 6. & Kelayakan desain & 1 & $100 \%$ & Sangat Layak \\
\hline 7. & Kelayakan kebahasaan & 1 & $80 \%$ & Sangat Layak \\
\hline 8. & $\mathbf{1}$ & $\mathbf{9 4 \%}$ & Sangat Layak \\
\hline Nilai rata-rata kelayakan & & & \\
\hline
\end{tabular}

Hasil uji kelayakan bahan ajar menghasilkan rasio kelayakan rata-rata 94\% berkategori sangat layak. Sehingga, peningkatan bahan ajar PBL-STEM untuk materi gerak lurus dapat dipergunakan sebagai sarana pembelajaran yang menunjang tercapainya peningkatan keahlian berpikir kritis serta pemecahan masalah fisika.

Uji keterbacaan bahan ajar yang telah dilakukan menghasilkan data kualitatif serta data kuantitatif yang diterima dari 15 siswa SMPN 24 Malang kelas VIII. Data kuantitatif didapatkan dari skor yang diberikan pada angket berskala Guttman. Dari hasil uji keterbacaan bahan ajar oleh 15 siswa kelas VIII terhadap 20 pernyataan terhadap bahan ajar yang dikembangkan, diperoleh presentase kelayakan $100 \%$ dengan kriteria yang sangat layak.

Berlandaskan dari hasil tes validitas kelayakan bahan ajar, bahan ajar berbasis PBL-STEM pada materi gerak lurus layak difungsikan sebagai peluang untuk meningkatkan kemampuan berpikir kritis .

\section{Simpulan \\ 4.1. Kesimpulan}

Bersumber pada hasil analisis dan pengkajian, dapat disimpulkan bahwa bahan ajar PBL-STEM materi gerak lurus yang telah dikembangkan patut untuk dipergunakan menjadi sarana pembelajaran bagi siswa SMP dengan rerata nilai uji 
kelayakan materi 96\% dengan tingkatan sangat layak, uji kelayakan aspek media 90\% dengan level sangat layak, uji keterbacaan guru 100\% dengan tingkat sangat layak, dan uji keterbacaan siswa 100\% dengan nilai sangat layak.

\subsection{Saran}

Sebelum melakukan proses belajar, alat dan media untuk pembelajaran harus benar-benar disiapkan. Guru harus bisa melakukan pembagian waktu dengan tepat, agar tahap pembelajaran terlaksana dengan baik. Materi harus sangat dipahami guru agar prosedur pengkajian memperoleh hasil yang baik.

\section{Daftar Rujukan}

Cahyaningsih, F., \& Roektiningroem, E. (2018). Pengaruh pembelajaran IPA berbasis STEM-PBL terhadap keterampilan berpikir kritis dan hasil belajar kognitif. Pend. Ilmu Pengetahuan Alam-S1, 7(5), 239244.

Darojatun. C.A. (2017). Analisis soft skills siswa dengan menggunakan model pembelajaran flipped classroom - collaborative learning pada materi redoks dan tata nama senyawa kimia. Skripsi. Jakarta: Universitas Negeri Jakarta.

Ennis, R. H. (2011). The nature of critical thinking: An outline of critical thinking dispositions and abilities. University of Illinois, 2(4).

Farwati, R., Permanasari, A., Firman, H., \& Suhery, T. (2018, March). Integrasi Problem Based Learning dalam STEM education berorientasi pada aktualisasi literasi lingkungan dan kreativitas. In Seminar Nasional Pendidikan IPA (Vol. 1, No. 1, pp. 198-206).

LaForce, M., Noble, E., \& Blackwell, C. (2017). Problem-based learning (PBL) and student interest in STEM careers: The roles of motivation and ability beliefs. Education Sciences, 7(4), 92.

Nuryanti, L., Zubaidah, S., \& Diantoro, M. (2018). Analisis kemampuan berpikir kritis siswa SMP. Jurnal Pendidikan: Teori, Penelitian, dan Pengembangan, 3(2), 155-158.

Maqbullah, S., Sumiati, T., \& Muqodas, I. (2018). Penerapan Model Problem Based Learning (PBL) untuk Meningkatkan Kemampuan Berpikir Kritis Siswa pada Pembelajaran IPA di Sekolah Dasar. Metodik Didaktik: Jurnal Pendidikan Ke-SD-an, 13(2).

Rachmawati, D., Suhery, T., \& Anom, K. (2017, October). Pengembangan modul kimia dasar berbasis STEM problem based learning pada materi laju reaksi untuk mahasiswa program studi pendidikan kimia. In Seminar Nasional Pendidikan IPA (Vol. 1, No. 1, pp. 239-248).

Satriani, A. (2017, October). Meningkatkan Kemampuan Berpikir Kritis Siswa Dalam Pembelajaran Kimia Dengan Mengintegrasikan Pendekatan Stem Dalam Pembelajaran Berbasis Masalah. In Seminar Nasional Pendidikan IPA (Vol. 1, No. 1, pp. 207-213).

Setyorini, U., Sukiswo, S. E., \& Subali, B. (2011). Penerapan model problem based learning untuk meningkatkan kemampuan berpikir kritis siswa SMP. Jurnal pendidikan fisika indonesia, 7(1).

Wibowo, A., \& Purnama, S. (2013). Pendidikan karakter di perguruan tinggi: Membangun karakter ideal mahasiswa di perguruan tinggi. Pustaka Pelajar.

Winarni, J., Zubaidah, S., \& Koes, S. (2016). STEM: apa, mengapa, dan bagaimana. Prosiding Semnas Pend IPA Pascasarjana UM, 1, 976-984. 